\title{
Decrying Shifting Norms: Towards a Codification of Societal Ethos in Akachi Adimora-Ezeigbo's HEART SONGS
}

\begin{abstract}
Akachi Adimora-Ezeigbo's literary forte in the last ten years has undoubtedly been fiction, but Heart Songs is her first collection of poems. In this collection, she takes on the roles of social commentator and crusader through the conduit of orature, to criticize the devaluation of cultural and societal norms. The Poetics of Heart Songs is imbued with: the lamentation of the dearth of moral and social values in Nigerian society; the actual but often unspoken degradation of Nigerian immigrants in Europe and America, and the frequency with which corrupt practices have undermined the nation's development. This paper examines how Heart Songs canvasses for a re-examination of societal ethos, which demands that Nigeria's present must settle with the past by recovering social, moral and cultural codes for the restoration of human dignity.
\end{abstract}

Key words

Decrying shifting norms; codification; societal ethos; cultural codes; Akachi Adimora-Ezeigbo

Akachi Adimora-Ezeigbo has distinguished and earned herself a respectable position among contemporary Nigerian writers, not only because of her prodigious contribution to the novelistic enterprise but also by virtue of her concern and passion for family cohesion in her children's books. This concern reiterates Lauretta Ngcobo's perception of a writer in African social milieu, "A writer observes and interprets the norms, the values and the customs of society. He or she affirms or negates those values according to his or her personal convictions. In this way he/ she creates or destroys social values. His/her interpretation will depend largely on 
his/her vantage point and could sway public opinion one way or another" (1988: 150). Adimora-Ezeigbo has drawn remarkably on Nigeria's political history to raise awareness of negative social, economic and political situations, demonstrating their consequences on society, and showing how those consequences can be lessened or reversed to the benefit of all. Despite her membership of the younger generation Nigerian writers, Adimora-Ezeigbo is no less determined than the older generation writers like Achebe and Soyinka and the radical writers like Femi Osofisan and Niyi Osundare in responding to social, political and cultural issues in which Nigerian nationhood is strikingly inscribed. This determination is vociferously embedded in Heart Songs, which has invariably provided a convenient artistic platform for measuring not only her poetic virtuosity, but also her passionate commitment to the restoration and preservation of societal intrinsic values. This paper examines how Adimora- Ezeigbo in Heart Songs criticizes a decline in social and cultural norms, which ostensibly reflects how contemporary Nigerian society has been weakened by its ambivalent positioning between poorly-digested western values and halfforgotten indigenous norms. Such positioning is often depicted in the portrayal of Nigeria as something of a cultural wasteland, in which time-honoured traditional values like honesty, selflessness and decency have lost ground to crass materialism, violence and selfishness. This is often depicted in the Nigerian literary works as exemplified by, Chinua Achebe's Anthills of the Savannah (1987), A Man of the People (1966), Niyi Osundare's Village Voices (1984), Odia Ofeimun's The Poet Lied (1980) and Cyprian Ekwensi's Jagua Nana (1961). The paper will further evaluate how the poetry collection deplores various poetic forms like myths, legends, satire and historical narratives to search for an alternative social vision to the Nigerian degenerating social and political system.

\section{Signification of oral tradition in Heart Songs}

The Poetics of Heart Songs is essentially rooted in the oral traditions, often called oral literature and more recently, orature. Orature in this paper refers to the distillation of intrinsic elements of traditional proverbs, anecdotes, legends, myths, tales, historical narratives and other creative appurtenances which facilitate poetic rendition of artistic performances for the purpose of harnessing aesthetic pleasure and satisfaction. Orature is employed as a convenient motif in the Heart Songs to rally against the desecration of cultural norms, and the distortion of social ethos in contemporary Nigeria. The appropriation of orature in the poetics of AdimoraEzeigbo's Heart Songs underscores Biodun Jeyifo's summation in IBA: Essays on African Literature in Honour of Oyin Ogunba, of the interface between written literature and non-written literature in the postcolonial societies:

Part of the reconfiguration of difference in the new perspectives on postcolonial literatures involves renegotiations of received notions of differences and distinctions between what is literature and what is not literature, be- 
tween so-called highbrow and popular literature, and between written and non-written oral and performative traditions which some theorists have given the name 'orature'. The great challenge here is to map and account for the complex relations between literature and what could be described as its cultural and artistic 'others'. (2003: 71)

Adimora-Ezeigbo draws a measure of influence from traditional African culture which resonates in her exploitation of considerable aesthetics inherent in the appurtenances of Igbo oral traditions, to examine the shift in social and cultural circumstances in post-civil war Nigeria.

David Lewis has defined social norms, "as customary rules of behaviour that coordinate our interactions with others. Once a particular way of doing things becomes established as a rule, it continues in force because we prefer to conform to the rule given the expectation that others are going to conform" (1969: 45). The transition between a definition of "social norm" and a definition of "social change" may be rigid at times but they may also be modified over time. But Immanuel Wallerstein agrees that "[c]hange is a very slippery word and is often used to blur the exact direction of the change" (1968: 5). However, a more expansive explanation of social change is provided in The International Encyclopedia of the Social Sciences as "the significant alteration of social structures (that is, of patterns of social action and interaction), including consequences and manifestations of such structures embodied in norms (rules of conduct), values and cultural products and symbols" (Sills 1972: 366). This definition ostensibly examines social change as a process utilized by a particular society to regulate its norms and values as demanded by prevailing circumstances. Such circumstances could manifest in social system, such as the obliteration of predominant social norms and values by alien social practices; significantly political, such as a sudden change in political system of a particular society; and economic, such as the evolution of new policies which significantly impinges on the way a given society earns its living.

A profound articulation of social change in Nigeria has come to constitute a major theme in Nigerian poetry. The choice of poetry as a literary vehicle for the depiction of social change in Nigeria has been fittingly captured in the words of Ode Ogede: "because of the very nature of poetry as an art form which gains its effects largely by indirect means, it would have seemed, ordinarily, surprising that poetry should stand first among the artistic genres found convenient by many Nigerian writers to their purpose of voicing social discontent" (1996: 65). Many poetry collections written by contemporary Nigerian poets have, for instance, discussed various shades of social change, ranging from corruption; military incursion into Nigerian politics; the Nigerian civil war; Niger-Delta crisis; and youths restiveness. A reflection of thematic preoccupations entrenched in social change in Nigeria are discernible in Ossie Enekwe's Broken Pots (1986); Niyi Osundare's Waiting Laughters (1990); Odia Ofeimun's The Poet Lied (1980); Pol Ndu's Songs for Seers (1974); Ezenwa Ohaeto's Songs of a Traveller (1986) and Femi 
Fatoba's Petals of Thought (1984), to mention but a few. In their quest to portray social change in their poetry, the post-war Nigerian poets in the words of J.O.J Nwachukwu-Agbada, "had to return to the local speech pattern so that, whether the poet is Hausa, Igbo, Yoruba, Urhobo or Nupe, there are linguistic models in his poetic afflation which every member of a Nigerian, if not an African, audience can relate to" (1991: 166). Heart Songs is replete with social and cultural concerns scattered in its eight sections: "Satirical Tunes"; "Praise Songs"; "Celebrating Lives"; "Njakiri”; "Songs in Pidgin"; "Gendered Musings"; "Love Songs"; "Random Songs"; "Memorial Songs" and "Songs for Women".

\section{Satirizing social ills}

"Satirical Tunes" focuses essentially on admixture of social themes to explore global issues of significance, as discernible in: "Ram Syndrome"; "Homeless", "The 'ism' of Race"; "Fallen Tyran"; "Lootocracy" and "Victim of our Wars". In these poems, vitriolic satiric jabs are ostensibly deplored at naked wield of power by the Nigerian political gladiators, in their desperate attempt to settle scores with their perceived critics and opponents.

The theme of global political repression is effusively sharpened against the backdrop of political dissent in Heart Songs. The compelling need to register significations of abuse of power from Nigeria to Russia provide a haunting spectacle of political liquidations, brutality and stupendous charging up of political atmosphere in "Ram Syndrome". Enormity of political assassination is rendered in the representation of the political gladiators and their victims in animal imagery. While the dictators are represented in the image of wild animals like, "Lion"; "Jackal"; "Spider" and "Cat", their victims are depicted as, "Antelope"; "Lizard"; "Grasshopper" and "Fly". Confluence of counterpointed words and their arrangement in the poem surreptitiously evinces a spectacle of the most egregious extermination of opposition and dissent voices in the tortuous post-civil war Nigerian political history. The use of animal imagery in the poem, underscores the weakness, victimhood and helplessness of the assassinated political opponents in comparison to the superior political apparatus wielded by the dictators. Consequently, considering the magnitude of political might at their disposal, it is easier for the dictators to ruin their victims effortlessly:

Grasshopper keeps

some distance

when it hears

the raucous music

of okpoko bird:

ask Dele Giwa

ask also race victim

Amadon Diallo (15) 
antelope does not leap

into lion's den:

ask ken Saro-wiwa (15)

The thematic preoccupation of "Ram Syndrome" is aptly animated by a quest for the conceptualization of sensibility beyond the realm of tyranny which is sublimated by the institutionalization of naked terror in Nigeria's political landscape. The poem reflects a harvest of deaths of prominent Nigerian politicians such as Chief M.K.O. Abiola and Chief Bola Ige; colourful Nigerian journalist, Dele Giwa, celebrated Nigerian writer, Ken Saro-Wiwa and defected Russian state agent, Alexander Litvinenko and the Russian dissident Anna Politkovskaya. The depiction of the killings of the personas in the poem is nuanced by Igbo anecdote, to mine the past political persecutions. The poem also condemns the tragedy of racism, hence a scathing allusion to the killing of Amadou Diallo a Senegalese immigrant that was killed by the overzealous white supremacist, American cops. Personas in the poem belong to the same political trajectory: they are all casualties of political persecution.

The condemnatory tone of abuse of power in "Ram Syndrome" vibrantly rings in the fusion of traditional and western elements of poetry. The poem makes a profuse use of poetic forms of oral tradition which dwell on proverbs, anecdotes and oral rhetorical questions. Stanzas one, two and three are grounded in proverbs and rhetorical questions translated from Igbo lore, and their usage in the poem provides a linguistic platform against which political assassinations are vehemently condemned.

\author{
From the ancients \\ Wise words: \\ He who consumes \\ The testicles of a ram \\ Owes ibi a debt - \\ Scrotum disease; \\ Penis pilfering \\ Prohibited: \\ Penalty? \\ Ram albatross \\ early symptom: \\ loss of favour \\ and patronage \\ the risk is all yours \\ to your peril \\ a scourge (14)
}

But while it is apparent that the title poem is modelled on Igbo witty saying which forewarns individuals to be careful enough not to have an intimate relationship with those who wield power, it may be difficult to ascertain if the majority of the 
readers could decipher the rhetoric of Igbo orature embedded in it. A thorough understanding of African cultural signification is essential for the decoding of the poetics of the title poem. Akachi-Ezeigbo's depiction of persecution, of dissent voices in the poem indicates that state-sponsored violence has metamorphosed into an aestheticized macabre that frighteningly consign political opponents into despair. Those who wield power are portrayed as lacking moral scruples, as their propensity for killing political opponents has no limits.

The dilemma of an African immigrant trapped in the streets of Europe and America without any optimism of change in fortune is horrendously problematized in "Homeless". The poem elucidates the plight of an illegal immigrant whose life is filled with an agonizing sense of displacement in the western world. AkachiEzeigbo's political concerns in the poem blend with the diaspora theme, where an individual's identity is principally constructed by the society one finds himself/ herself, rather than something one is. The illegal immigrant in the poem suffers a double disappointment: he is estranged from his country socially by suffering unemployment and then finds himself alienated from the social setting of the western world, which has no tolerance for people of the black race. The poem serves as the framework for evaluating the dreadful theme of racism in Europe and America:

What are you?

Stray dog

Or illegal immigrant?

Britons empathize with

the former, not the latter

living on the street

robs you of your humanity ... (18)

The poem does not only portray a vicious racial prejudice against the black man by the Britons, it is also a social and political statement on the status of an illegal immigrant as poignantly constructed by the British society. In the aesthetics of racism underlined in the poem, rejection becomes a vocabulary, and alienation becomes narrative of immigration. Although the poet does not subscribe to illegal immigration, but not surprisingly, the poet condemns the humiliating and despicable treatment suffered by the immigrant.

The "Ism" of Race chronicles a harrowing experience of an emigrant. The theme of emigration and the quest for acceptability constitute the locale of the poem. There can be no doubt that Ezeigbo does a very clever riff on the psychological impact of racism on people of black race in the poem:

Wouldn't look

People in the eye

fearing they'd

frown (20)

Juxtaposed against these lines: 


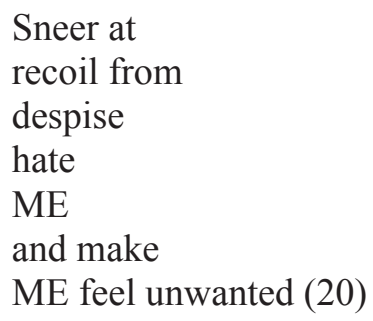

Unobtrusively, the poem dwells on the intercontinental discourse which interfaces with the trajectory of younger generation Africans unanchored, rudderless and adrift in a continent that provides them with no gainful employment and meaningful future. Consequently, immigration to Europe and America provides the emigrants with an escape from poverty, shame and degradation. But such escape from Africa does not bring about the much sought after succor for the emigrants, as interaction with the culture of their host countries is "inflected very much by the historical, linguistic and political situatedness of different sorts of actors" (Apparadurai 1996: 296). This cultural shock weighs down on the emigrants as they constantly get exposed to the racial complexities inherent in the host countries. Phrases like sneer at, recoil from, despise, hate Me, and make ME feel unwanted underscore signifiers of racism in the poem, and are exteriorized as a signification of the emigrants' often unresolved negotiation of a dialogic identity, which has strident parallelism in Apparadurai's theorization on how globalization impacted on culture:

We are looking at the birth of a variety of complex, postnational social formations. These formations are now organized around principles of finance, recruitment, coordination, communication, and reproduction that are fundamentally postnational and not just multinational or international.[They]are more diverse, more fluid, more ad hoc ... less organized, and simply less implicated in the comparative advantage of the nation-state. (1996: 167)

The problematic of the new globalizing processes as expressed through their distinctive forms of social life has also caught the attention of Mike Featherstone, who enthuses that globalization poses a challenge to sociology's concern with the society as a bounded nation state, in its attempt at, "opening up another space onto which can be inscribed speculative theorizations, thin histories and the detritus of the exotic and spectacular" (1999: 2). An evaluation of these theoretizations in relation to the social and psychological connection between the emigrants and their host communities reveal a complicated contestation between the national and global interests.

Artistic celebration of the triumph of good over evil is remarkably explored in Heart Songs. A transfer of political power from oppressor to the oppressed is underscored when a society rewrites its people's history, as evaluated in "Fallen Tyrants". The poem underlines a change in the power base when such re-writing ushered in a paradoxical reality: The transfer of political power from oppressor 
to the oppressed, ineluctably brings in its wake the appropriation of hegemony and power apparatuses to the oppressed. For the erstwhile oppressors, however, shock, sorrow, anger, that accompany the loss of power take precedence:

\author{
Return journey \\ Is shorter than outward journey \\ Ask those who plied the route before \\ Adolf Hitler, Idi Amin, Mobutu, Pinochet- \\ Is there a sting without antidote? \\ Is there a tree that can populate a forest? \\ Those who thrive by sword \\ Will not escape its sharp-edged justice (22)
}

The poem is a play up of man's inhumanity to man in a frightening magnitude, the trajectory of abuse of power located in the brutality and killings carried out by erstwhile dictators such as, Idi Amin Dada of Uganda, Adolf Hitler, Augustus Pinochet, and Mobutu Seseseko, is rhetorically interrogated through the employment of satirical irony and mocking sarcasm. However, the poem concludes that such brutality also has a terminal point which is usually marked by a historic change of power. While "Fallen Tyrant" depicts the cruelties inflicted by the dictators and its name places the burden of guilt on power, its operation itself attracts oppression and brutality as its characteristics.

Concomitant with the task of mounting a crusade against the devaluation of social ethos in Nigerian society, the anthology assiduously criticizes corruption in contemporary Nigeria. Its devastating effect is disturbingly horrifying to the extent that moderation and sensibility have lost their meanings in the mad rush by the politicians to loot the state treasury, as prebendalism holds sway. "Lootocracy" reflects the spate of corruption that has plagued Nigeria since its return to democratic governance in 1999. The poem takes us through the interlocking trajectory of corruption frequently encountered in the poem: "The clowns in a game of greed", "adopt this as their creed", "uproot caution", "enthrone indiscretion", "in the orchard of lootocracy". These interlocks ostensibly allude to the rapacious stealing of public wealth in the country by the political class. Perhaps nowhere in contemporary Nigerian literature is the graphic illustration of brazen looting of public treasury given a sounder expression than in Adimora-Ezeigbo's Heart Songs. The role of an artist as a commentator on public issues which impinges on the well-being of African society, has been essentially articulated by Chinweizu et al: "the function of the artist in Africa, in keeping with our traditions and needs, demands that the writer, as a public voice, assume the responsibility to reflect public concerns in his writings, and not preoccupy himself with his puny ego" (1983: 19). The poet's fulfilment of this mandatory role is sufficiently grounded in the strident condemnation of corruption in the poem, which comes into an even clearer focus, if we consider the depiction of Nigerian politicians' greed for material things, done with attendant manipulative tactics: 
Wisdom twisted

Black signifies white

White turns black

Shroud of reason (24)

These lines serve as an important indicator of the extent to which morality and decorum have been thrown overboard by the political class in their desperate struggle to bleed the country white.

Most postcolonial African countries have experienced war and civil strife at one time or another, due to reasons ranging from ethnic conflict, political mismanagement of economic resources to a flagrant abuse of power. Countries like Nigeria, Rwanda, Burundi and most recently Cote d'Ivoire have experienced civil war with its attendant costs, in human displacement, killings and destruction of properties and public infrastructures. This underscores Josaphat Kubayanda's opinion that:

Tyranny is an endemic social and political problem in Africa and Latin America. An authoritarian reality similar to colonialism replaced the utopian dream underlying the movement for independence on those continents. Literary works from those regions portray totalizing codes that pinpoint an unfinished business of decolonization, for independence seems to be a selfserving arrangement between the European colonial centres and the emergent ruling elites of the African and Latin American colonies (1997: 38).

The impact of war on African societies constitutes an important discourse in "Victims of our wars". Internecine war in most African countries is subordinated to the unleashing of terror and brutality on women and children:

Women who lost their children

Babies without breasts to suck

Multitudes without homes to return to

Millions of women defiled, violated (26)

The poem does not only condemn war and its corresponding devastating impact on women and children: but it emphasizes that war manifests anguish which leaves the "orphans in limbo, rootless" and "Thousands of victims who lost their minds to grief" as casualties of the senseless war.

\section{Celebrating tradition}

The use of myths, folktale techniques, proverbs, rituals and witty sayings as poetic elements by the contemporary Nigerian poets is often done to achieve a balance between the western civilization and the African cultural tradition. For Adimora-Ezeigbo, African tradition, albeit Igbo cultural exegesis fittingly provides 
a vehicle of cultural recuperation. This is borne out of her conviction that cultural revivalism serves as the authentic blueprint, for the realization of moral rejuvenation in Nigeria's quest for the elusive moral and social orders. "Uhamiri's Haven" enthuses the beauty of Ugwuta lake whose splendour is grounded in the mythologisation of Uhamiri. In her popular novel Efuru, Flora Nwapa has transformed Uhamiri, the water goddess of Ugwuta lake into a symbol of feminine power. "Her service, the price of which is the barrenness dreaded in the traditional patriarchal system, becomes a symbol of the possibilities for an independent female life, meaningful in its own terms, and not a mere adjunct to male needs" (Griffith 2000: 286). The portrayal of Uhamiri in the poem has succinctly demonstrated that the supernatural does have a place in literature, especially in African societies, where alternative belief system holds sway. This underscores the notion that Africans ostensibly subscribe to the significance of the supernatural as part of its existentialism, despite sustained western scepticism about its existence.

Uhamiri's symbolic nature is represented, in the following:

Woman of the lake

Relic of the past, you linger in our memory

You who held sway in days gone by

Powerful deity, beautiful goddess

Your watery presence was... (28)

The aestheticization of Uhamiri in the poem is reminiscent of Christopher's Okigbo's supplication to "Mother Idoto".

Before you Mother Idoto, naked I stand:

before your watery presence

a prodigal

leaning on an oilbean

lost in your legend.

Under your power wait I

On barefoot

watchman for the watchword

at Heavensgate; (3)

Here, Okigbo has embarked on a cleansing rite required for his reintegration into his communal belief system. A process which entails a symbolic act of ritualistic engagement in the form of bathing, meditating and offering of somber supplication to the water deity, Idoto. However, Okigbo's gesture towards Idoto is borne out of sobriety and penitence, whereas Adimora-Ezeigbo's gesture towards Uhamiri is that of reverence and profound admiration. This is underscored by the accentuation of Uhamiri's qualities in the poem to project African tradition. The weaving 
of diverse images around metaphysical and mythical objects in African cultural milieu underlies Catherine Acholonu's observation that, "In traditional African religion, religious practice is evocative; as in the religion of the Negro spiritual, faith is expressed through the invocation of a god. In this ritual, which is a form of occultism or magic, three main vehicles abound. These are: dance, drum (flute, or other musical instruments) and the spoken word, which is recited or sung..." (1991: 138). In drawing our attention to the resplendent charm and mystique of Uhamiri, Adimora-Ezeigbo reiterates atmosphere which enhances the logos of her myth.

O Goddess, our eyes lit up to behold your zone

Sunshine courted you swooned upon you

Intoxicated by your depth, your wide girth.

Your calm sweetness held him captive

As reward for your hospitality, your invitation

... your beauty exploding in scintillation

Birthing a galaxy of stars on water (28)

The embedding of myth, cultural symbols and legend in "Uhamiri's Haven" is essentially crafted to reinforce respect for tradition and time honoured values, and to emphasize the placement of the supernatural in his or her assigned place in the cosmos.

\section{Recuperating societal ethos}

In dogged determination to infuse moral balance into a fast disintegrating world of the youths in contemporary Nigeria as captured in "Cultism", Adimora-Ezeigbo beams her searchlight on the menace of cultism in Nigeria's tertiary institutions. The poem presents a frank and blunt criticism of the moral decadence inherent in cultism:

But dis secret cult no be mistake

$\mathrm{Na}$ real crime, proper murder

As dem cultist just dey butcher people (38)
But the secret cult is not a mistake

It's a real crime, a murder

The cultists just kill people

Attention is profoundly focused on the menace of cultism, and emotion is betrayed in the evaluation of senseless killing as its consequent attendance. Nevertheless, that the poem is written in pidgin English, it dwells on complex social reality which has negatively contributed to the disruption of academic programmes in most Nigerian tertiary institutions.

School dem no wan go again

they are not ready to go to school again 
Lecturers dey chop money for nothing

De youths no wan stay for class room (38)
Lecturers are just earning salary without teaching the youths do not want to go for classes again

The poem is grounded on satiric evaluation of a malignant social malaise plaguing Nigerian society. The appropriation of pidgin, patois and the indigenization of European language words by the contemporary African writers is consciously done to create an alternative platform, for the articulation of social and political situations as they unfold on the present continuous basis. Pidgin English affords the poet to appropriate poetic idiom and form to express her dismay at this virulent social miasma. In this vein, we find her employment of humour to ridicule this social scourge very appropriate.

Like joke, like joke, de pickin dey drug

Dem smoke grass-igbo, wee wee

Kaikai dem drink like water sef

Womanize pass sojaman and sailor (38)
Like joke, like joke the child takes drug they smoke marijuana drink gin like water Womanize more than soldiers and sailors

Humour in the poem provides an elaboration of the depth and magnitude of cultism as a debilitating social problem. Humour in Pidgin English has been evaluated by Ezenwa Ohaeto as a linguistic variable which, "enables the writer in pidgin to explore social reality insightfully and interestingly, because it is achieved through the use of hilarious allusions, ironic perceptions, succinct imagery and the tabulations of incongruities in human behaviour" (1994: 49). The use of humour in the poem, provides shades of illustration on the inner-workings of cultism among the youths. The graphic illustrations of grass-igbo, wee-wee; kaikai as stimulants among the cultists, provide an average Nigerian reader a robust explanation on the negative effects of hard drugs.

A criticism of an obsession with the modern fashion trend is dramatized diagrammatically in "Nudity". The obscenity associated with the exposure of vital parts of woman's anatomy through the wearing of skimpy dresses is ludicrously caricatured in the poem. Adimora-Ezeigbo skilfully engages the humanistic morals in her artistic effort to discuss the negative fashion trend in the Nigerian society, where women have imbibed a wide range of alien values which are antithetical to the social norms and values engrained in African cultural sensibility. The poem satirizes the devaluation of womanhood, underscored by topless, striptease, show belly and show bobby. Ultimately, what gives coherence to the assault on women's dignity as reflected in the poem may not be the title of the poem, but how Adimora-Ezeigbo, by appropriating a potent physiological concern, of the poor dressing habit, turns a negative fashion fad into social discourse that she uses to create new frames of 
understanding about Nigerian women's obsession with debasing fashion culture. This reiterates the significance of the artists as the bastion for reconstructing the society as opined by Roy Hearth: "it is our creative artists, our writers, painters, sculptors, and musicians that we must look to rebuild a shattered tradition..." (1972: 91). Addressing this significant social issue constitutes a certain assertion of authority on the part of the poet. In asserting such authority, the poet ostensibly, has clinically dealt a telling blow to a subversive fashion trend among women in Nigeria. The significance given to the distortion of women's anatomy in "Nudity" is contained in the condemnation launched at the despicable fashion trend:

Che, which kind madness

Catch women for present time?

Abi na my eye only de see am?

De ting dey ground since new millennium this?

But, every year na him de ting get worse

Like fire wey catch dry forest for Harmattan (40)
What! What type of madness

Is affecting our women these days?

I do hope I am not the only one seeing this?

It started in this millennium

But, it gets worse every year

Like the forest fire in the Harmattan

A post-modernist depiction of women in African literature is foreshadowed by the new literary direction which stridently calls for the re-construction of African womanhood as "to rewrite and represent women as individuals with conscience, able to question the system that marginalises and disempowers women" (Onwueme 2003: 8). "Power to the women" is an advocacy for gender equality in Africa. The poem repudiates the relegation of women to the background, and makes a strident call for the overturning of this tradition, as to advance a modern African society. The poem unavoidably stresses women's position in contemporary Africa's socio-political scheme, especially in the economic production processes.

\section{Empowering women \\ Is key to improvement \\ For women's lives \\ For children's lives (61)}

The poem further articulates the significance of women's empowerment as a panacea to social tension in family relationship in African post-colonial societies, where there is a growing level of family dislocation as a result of the lopsided gender stratification:

Gender equality

Marches hand in hand

With children's well being 
Produces prosperity and

Harmony in homes

Welcoming it (61-62)

In these lines, cultural practices aimed at curtailing women's social relevance, and merely portraying them as mothers and wives are obliquely repudiated. The poem encourages every woman to create an individuality, a separate personhood in an African environment notorious for stifling female self-fulfilment and economic emancipation. The need to take seriously the issue of corporate and moral responsibility among Nigerian politicians is the main preoccupation in "Brave Stab". The poem calls for a close reading of criticism of corruption and idleness of the Nigerian politicians who fittingly situated against the backdrop "of postcolonial African political struggles" in which "the language of inequality continues to revolve around the metaphors of eating and, by extension, cannibalistic consumption. The trope of cannibalism as a symbol for economic exploitation, material accumulation, and violent coercion carried out by postcolonial elites has, in fact, come to dominate African political discourse" (Matthew Christensen 2005: $3)$. The poem within the context of political realities of Nigerian society, provides an overview of the moral recklessness of the politicians, who are irredeemably indulging in sexual proclivities rather than getting preoccupied with commitment to governance. While frowning at the negative attitude of the politicians in carrying out business of governance, "Brave Stab" is eloquently entrenched in a satire, to repudiate the politicians' gratuitous obsession with sex:

These men permanently

Stand for erection

Rather than election

The nation must

Call them to

Attention!

Sex scandal

must cease (94-95)

The poem in an acerbic, derisive tone, points out the ironical recklessness nature of the politicians, where:

Sex pushed

High up

The agenda

In place of

National agenda (95)

Here, serious business of governance is juxtaposed with the debauched style of hopping from one woman to the other in a mad rush to enjoy passion and pleas- 
ure. The poem evokes a notion of triviality in administering governance, and reminds one of frivolity and levity with which the apparatchiks entrusted with the destiny of the nation compromise standards of governance.

A modernist haunting and disturbing historical reference point in Nigeria's political history, the despoliation of the Niger Delta region is revisited in "Violated Ogoni women". Yet, while the poem is certainly drawing attention to the marginality of Ogoni land in particular, and Niger Delta in general, it nonetheless amplifies the violence visited on the women by the men of joint task force, who raped, maimed and killed scores of women in Ogoni land. During its campaign for minority rights assertion by the late Ken Saro-Wiwa, to expose the conspiracy of the Shell Petroleum Company and General Sanni Abacha's rule of terror, Ogoni land was turned into a battlefield where all sorts of crime against humanity were orchestrated with impunity.

... you watch your daughters

ravaged

by men armed

to the teeth

some younger than you:

men of blood

on a blood-drinking

spree ... (124)

Reading the poem within the context of Nigerian political discourse, on the other hand, enables Adimora-Ezeigbo to embark on a broader construction of African political problematic, so as to underscore the impact of violence on women in African political terrain:

Sisters, wipe your tears

Many before you

This path have walked -

Biafra remote arena

Rwanda only yesterday ... (124-125)

"Violated Ogoni women" raises questions of violence and the murky politics of oil exploration in contemporary Nigeria to contest the serving claims of restoration of law and order made by the dubious Abacha's military junta. Ogoni was invaded, violated and transgressed for the purpose of maintaining continuity in oil exploration, in the face of people's contestation of their marginality in terms of environmental degradation which has been recorded as a fall out of government's insensitivity to the plight of the Niger Delta in Nigeria. In the context of Nigeria's contestable political structuring, which reverberates in the yoking together of dissimilar ethnic groups and cultures by the colonial apparatus, consequently, the language of inequality continues to revolve around the metaphors of neglect and, 
by extension, military adventurism. Tropes of military adventurism and political merchandising serve as euphemisms for brigandage, corruption and atrocious brutality, which, in fact, dexterously resonates with a dominant Nigerian political discourse in the poem. Hence, "Biafra remote arena", "men of blood", "many before you this path have walked", and "ravage" only serve as collocational gambits of Nigeria's susceptibility to disintegration.

\section{Conclusion}

Heart Songs is preoccupied with the dilemma of shifting norms in the contemporary Nigeria. Adimora-Ezeigbo's presentation of a compelling portrait of $\mathrm{Ni}$ gerian society in motion is done with a corresponding artistic platform for the evaluation of the discernible clash between the old and the new, or the clash of two opposing layers of cultural norms, the authentic African socio-cultural norms and the emerging European/American cultural practices/ attitudes. Inevitably, issues of moral and political corruption, racism, dictatorship and the devaluation of cultural ethos palpably constitute the essential thematic focuses in the anthology. In conclusion, this paper has discussed how Heart Songs has intricately examined the subversion and the devaluation of societal ethos by the shifting norms in contemporary Nigeria. Through exposition of these anomalies, formulated across a network of concerns and positions, especially in response to specific and changing social, cultural and political circumstances, Adimora-Ezeigbo in this poetry collection has convincingly canvassed for a return to social, political and cultural foundations on which durable norms could be built.

\section{References}

Achebe, Chinua (1987) Anthills of the Savannah. London: Heinemann.

Achebe, Chinua (1966) A Man of the People. London: Heinemann.

Adimora-Ezeigbo, Akachi (2009) Heart Songs. Ibadan: Kraft Books Limited.

Acholonu, Catherine (1991) "From Rhetoric to Occultism: The Word as Music \& Drama in Okigbo's Labyrinths". African Literature Today 17 (1), 138.

Apparadurai, Arjun (1996) Modernity at Large: Cultural Dimensions of Globalization. Minneapolis and London: University of Minnesota Press.

Apparadurai, Arjun (1999) "Disjuncture and Difference in the Global Cultural Economy". In: Featherstone, Mike (ed.) Global Culture: Nationalism, Globalisation and Modernity. London: Sage, 295-310.

Chinweizu Onwuchekwa, Jemie and Ihechukwu Madubuike (eds.) (1983) Toward the Decolonization of African Literature. Washington D.C: Howard University Press.

Christensen, Matthew (2005) "Cannibals in the Postcolony: Sierra Leone's Intersecting Hegemonies in Charlie Haffner's Slave Revolt Drama Amistad Kata-Kata". Research in African Literatures 36 (1), 3.

Encyclopedia of the Social Sciences. Vol.11. (1972) Ed. David L. Sills. New York: Macmillan.

Ekwensi, Cyprian (1979) Jagua Nana. Ibadan: Heinemann. 
Enekwe, Ossie (1986) Broken Pots. Nsukka: Afa Press.

Fatoba, Femi (1984) Petals of Thought. London:New Beacon Books.

Griffith, Gareth (2000) African Literature in English: East and West. Harlow: Pearson.

Hearth, Roy (1972) “The Function of Myth". In: Salkey, Andrew (ed.) Caribbean Essays. London: Evans, 86-94.

Jeyifo, Biodun (2003) "New Perspectives on the Postcolonial Literatures of the Developing World". In: Ogundele, Wole and Gbemisola Adeoti (eds.) IBA: Essays On African Literature in Honour of Oyin Ogunba. Ile-Ife: Obafemi Awolowo University Press Ltd.

Kubayanda, Josaphat (1997) "Unfinished Business: Dictatorial Literature of Post-Independence Latin America and Africa". Research in African Literatures 28 (4), 38.

Lewis, David (1969) Convention: A Philosophical Study. Cambridge MA: Harvard University Press.

Ndu, Pol (1974) Songs for Seers. New York: Nok Publishers.

Ngcobo, Lauretta (1988) “African Motherhood- Myth and Reality”. In: Holst Petersen, Kirstein (ed.) Criticism and Ideology: Second African Writers' Conference Stockholm 1986. Uppsala: Scandinavian Institute of African Studies, 150.

Nwachukwu-Agbada, J.O.J. (1991) "The Language of Post-war Nigerian Poetry of English Expression". African Literature Today 17, 166.

Nwapa, Flora (1966) Efuru. London: Heinemann.

Ofeimun, Odia (1980) The Poet Lied. London: Longman.

Ogede, Ode (1996) "Poetry \& Repression in Contemporary Nigeria: Tanure Ojaide's Labyrinths of the Delta". African Literature Today 20, 65.

Ohaeto, Ezenwa (1994) "Pidgin Literature, Criticism \& Communication". African Literature Today $19,49$.

Ohaeto, Ezenwa (1986) Songs of a Traveller. Awka: Towncrier Publications.

Okigbo, Christopher (1971) Labyrinths. London: Heinemann.

Onwueme, Tess (2003) Personal Interview. Eau Claire, Wisconsin. June 8.

Osundare, Niyi (1984) Village Voices. Ibadan: Evans.

Osundare, Niyi (1990) Waiting Laughters. Lagos:Malthouse.

Wallerstein, Immanuel (1968) Social Change: The Colonial Situation. New York: John Wiley.

NIYI AkINGBe is Senior Lecturer, and teaches English Studies at the Ondo State University of Science and Technology, Okitipupa, Ondo state, Nigeria. He received BA in English Studies at the Obafemi Awolowo University, Ile Ife, Nigeria. He received both MA in Literature and Ph.D in English at the University of Lagos, Akoka, Nigeria. His articles have appeared in Matatu; Transnational Literature; Journal Of Postcolonial Cultures and Societies; California Linguistic Notes and other scholarly journals on African Literature. He has also written two critical works: Myth, Orality and Tradition in Ben Okri's Literary Landscape and Social Protest and the Literary Imagination in Nigerian Novels. He is currently on the editorial board of Journal of Postcolonial Cultures and Societies, Wright State University, USA.

Address: Dr. Niyi Akingbe, English Studies Unit, Ondo State University of Science and Technology, P.M.B 353 Okitipupa, 350001 Okitipupa, Ondo state, Nigeria. [email: deniakingbe@yahoo. com] 
